\title{
Household Saving Behavior and Determinants of Savings in Financial Institutions: The Case of Derra District, Oromia Region, Ethiopia
}

\author{
Abate Tadesse Zeleke* \\ Statistics department, Madda Walabu University, PO box 247, Bale-Robe, Ethiopia \\ Ahmed Kelil Endris \\ Human resource director, Derra Hospital, Gundo Meskel, Ethiopia
}

\begin{abstract}
Saving is the fraction of income not instantly consumed but kept for future investment, consumption or for unforeseen contingencies in the future. The aim of this study was to investigate the saving behavior of household and determinants of saving in the district using primary data from 249 samples of household. The analysis used descriptive and inferential analysis to achieve the objective the study. The descriptive part showed that about $14.5 \%$ of the household were not saving in financial institutions whereas about $85.5 \%$ saved in financial institution. The chi-square test of association revealed that Age of household head, education level of household head, main occupation, knowing about the interest rate of financial institution, having farm land, getting advice about saving were significantly associated the saving status of households. Additionally, the logistic regression showed that age of household, main occupations, knowing about interest rates, income of households and family size were significant determinants of households saving status. In order to enhance the households saving status in financial institutions, the district, the Oromia regional state and the government financial sectors should work on awareness creation about saving and increase the income of the household.
\end{abstract}

Keywords: Financial institution; Logistic regression; Saving Status

DOI: $10.7176 /$ RJFA/10-23-03

Publication date: December $31^{\text {st }} 2019$

\section{INTRODUCTION}

Saving is the fraction of income not immediately consumed but kept for future investment, consumption or for unforeseen incidents. It also used in improving the well-being of individuals and serve as a security at the times of shocks for the households. In developing countries savings are important factors of households' well-being. Individuals and households savings provide a cushion of security against future incident whereas for nation savings provide the funds needed in the developmental efforts (Gedela, 2012). In addition, saving enable households to maintain a stable life time level of living and it is also likely to refrain from current consumption to save for payment for children's education (Yao et al., 2011). Unexpected events in the life-cycle of individuals make saving an important element in fulfilling the financial gap (Popovici 2012).

In many developing economies mainly Africa, saving and investment are necessary engines for capital formation and economic growth. It has been claimed that saving constitutes the basis for capital formation and capital formation constitutes a critical factor of economic growth. Saving in developing countries is not only used as the means of accumulating wealth but also used as smoothing consumption in face of the volatile and unpredictable income and helping to ensure the living standards of poor people whose lives are difficult and uncertain (Oladipo, 2010).

Households savings in developing countries particularly in Sub-Saharan Africa remains limited and far behind from other parts of the world. This is due to high levels of unemployment, low level of income, the engagement of a large proportion of the population in the informal sector and poor performance of the economy (Karim, 2010). In developing countries like Ethiopia, economic fluctuations and climate risk lead to important income variations and leave the households vulnerable to severe hardship. Besides, their social coverage is limited and the financial markets are not well developed. Consequently, these countries often face saving allocation problems and have difficulties to develop productive investments (Tsega and Yemane, 2014). The saving habit of developing countries has been hindered by different factors such as inadequate financial service, physical distance from financial institution, little incentive to save, low interest rate and lack of adequate income to save (Ondiege, 2012).

For the developing countries including Ethiopian, the household savings rate is a prime cause for the highs or lows economic development and influencing the overall economic scenario. Countries having higher level of saving rates have managed to reduce the burden of foreign debt and thus domestic investments will be financed by domestic saving especially household sectors (Tadele, 2015).

In Ethiopia as well as in Derra district, there are formal and informal financial and non-financial institutions 
which serves the community in their daily financial activity. In Ethiopia different studies were done and identify the different factors related to the households saving behaviors such as Mirach and Hailu,(2014) study showed $54.1 \%$ of sample households practiced saving and the common reasons for households not to save are low income, inflation, low interest rate, cultural background, education, social affairs and unemployment. In addition, study by Bizuneh (2011), Mirach and Hailu (2014), Halefom (2015) and Saliya A. (2018), using tobit model showed that income, age, sex, education and forms of institutions used for saving are significant determinants of household savings. However, these studies did not consider the saving behavior in financial institution explicitly. Hence, this study tried to assess and investigate the saving behavior of the households and factors related with it in the financial institution in the district using chi-square test of association and logit model.

\section{DATA AND METHODS}

\subsection{Study area and Data}

The study conducted in Derra district. The district is one of the 18 districts of the North Shewa Administrative Zone, which is located in Oromia Regional State of Ethiopia. It is $213 \mathrm{~km}$ far from Addis Ababa, the capital city of Ethiopia. The district is located between $12^{\circ} 92^{\prime}-13^{\circ} 12^{\prime} \mathrm{N}$ latitude and $34^{\circ} 40^{\prime}-35^{\circ} 80^{\prime} \mathrm{E}$ longitude and elevation from $1798 \mathrm{~m}$ to $2118 \mathrm{~m}$ above sea level. The administrative center of Derra is Gundo Meskel (CSA, 2011). A total of 217,292 people live in the district (CSA Population Projection, 2013).

In order to achieve the objective of the study, primary data source was used from the household who live in the study area through survey based structured questionnaire. These data on socioeconomic, demographic and saving behavior of the respondent was collected using face-to-face interview from July 20 to August 30, 2019.

\subsection{Sampling Procedure and Sample size determination}

\subsubsection{Sampling procedure}

A three stage sampling techniques used to select the representative households from the study area. At first stage, Dera district is selected purposively taking into consideration time, budget, and accessibility issues to investigate the saving behavior of the community. Secondly, 4 kebeles (3 out of 30 rural kebeles and 1 out of 4 urban kebeles) were selected randomly to yield maximum precision per cost, minimize bias and to give equal chance to be sampled for kebeles (Cochran, 1977). Thirdly, 249 Households were selected using systematic random sampling technique and interviewed.

\subsubsection{Sample size determination}

The sample size ( $\mathrm{n}$ ) is determined using the statistical formula $\mathrm{n}=N / 1+N e^{2}$ (Yemane1967), Where $\mathrm{n}$ is sample size, $\mathrm{N}$ total rural household in the three kebeles, e is precision or margin of error (5\%).

$$
\mathrm{n}=\frac{N}{1+N e^{2}}=\mathrm{n}=\frac{N}{1+N e^{2}}=\frac{2347}{1+2347\left(0.06^{2}\right)}=\frac{2347}{1+8.8675}=248.4=249
$$

Lastly, the total sample size is allocated to each kebeles using proportion to size allocation methods. $\mathrm{n}_{\mathrm{h}}=$ $\mathrm{N}_{\mathrm{h}} / \mathrm{N}^{*} \mathrm{n}$

\begin{tabular}{|l|l|l|}
\hline \multicolumn{1}{|c|}{ Kebeles } & \multicolumn{1}{|c|}{ HH size $\left(\mathrm{N}_{\mathrm{h}}\right)$} & \multicolumn{1}{c|}{ Sample Size $\left(\mathrm{n}_{\mathrm{h}}\right)$} \\
\hline Dembi Birjie & 840 & 89 \\
\hline Gundomeskel 02 & 425 & 45 \\
\hline Ada'a Melkie & 654 & 69 \\
\hline Selelkula & 428 & 46 \\
\hline Total & 2347 & 249 \\
\hline
\end{tabular}

\subsection{Study variables}

Dependent Variable: Saving behaviors of the household which could be saving status (if the household not saved in financial institution coded as 1 or 0 otherwise)

Independent variables: are variables expected to influence the saving characteristics of household which could be socio-economic, demographic and institutional factors. These variables are:

Gender Household head

Age of Household head

Marital Status

Family size

Religion

Education level

Place of Residence (kebele)

Main occupation

Income of households

Having own farm land 
Having livestock

Getting advice to save

Prefer type of financial institution

Know interest rate

Distance to Financial institution

\subsection{Method of Data Analysis}

The study used descriptive and inferential statistics to achieve the aim of the study. From descriptive statistics, it used percentages, means, cross tabulation, charts, standard deviations, and from inferential statistics it used chisquare test of association and binary logistic regression to identify the major behaviors of saving and factors associated with household saving activity.

\subsubsection{Binary Logistic regression model}

The binary logistic regression procedure empowers one to select the predictive model for dichotomous dependent variables. It describes the relationship between a dichotomous response variable and a set of explanatory variables. The explanatory variables may be continuous or discrete (McCullagh and Nelder, 1989). Binary response models are of major importance in the social sciences as well as in demography since many social phenomena are discrete or qualitative rather than continuous or quantitative in nature. In such studies, the logistic regression model has become the statistical model of choice (Agresti, 2007).

For this study, the binary logistic regression model used to investigate effect of predictors on the probability of the response variables (saving status of households) $\left(\mathrm{Y}_{\mathrm{i}}\right)$ given at Derra district which is defined as follows. $Y_{i}$ coded as 1 if the respondent not saved in financial institution and 0 other wise. Where: $-i=1,2 \ldots n$ and $n$ is the number of households who are sampled.

Let us denote the proportion of success (not saved money in financial institution)

$$
\begin{array}{r}
p\left(Y_{i}=1\right)=\pi_{i j}, p\left(Y_{i j}=1\right)=1-\pi_{i j} \\
\text { and } \mathrm{Y}_{\mathrm{i}} \sim \operatorname{Bernoulli}\left(\pi_{\mathrm{i}}\right)
\end{array}
$$

Let $\mathbf{X}_{\mathrm{nx}(\mathrm{k}+1)}$ denote the single level binary logistic regression data matrix of $\mathrm{k}$ predicator variables of the saving status and $\boldsymbol{\beta}_{(\mathrm{k}+1) \mathbf{x} 1}$ be a vector of coefficients and given as:

$$
X=\left[\begin{array}{ccccc}
1 & x_{11} & x_{12} & \ldots & x_{1 k} \\
1 & x_{21} & x_{22} & \ldots & X_{2 k} \\
\vdots & \ldots & \ldots & \ldots & \vdots \\
1 & x_{n 1} & x_{n 2} & \ldots & x_{n k}
\end{array}\right] \quad \beta=\left[\begin{array}{c}
\beta_{o} \\
\beta_{1} \\
\vdots \\
\beta_{k}
\end{array}\right]
$$

$\mathrm{X}$-is the design matrix

$\beta$ - is the vector of unknown coefficients of the covariates and intercept Then, the logistic regression function is given as:

$$
\pi_{i}=\frac{\exp \left(\beta_{o}+\beta_{1} X_{i 1}+\beta_{2} X_{i 2}+\ldots+\beta_{k} X_{i k}\right)}{1+\exp \left(\beta_{o}+\beta_{1} X_{i 1}+\beta_{2} X_{i 2}+\ldots+\beta_{k} X_{i k}\right)}=\frac{\exp \left(X_{i}^{\prime} \beta\right)}{1+\exp \left(X_{i}^{\prime} \beta\right)}
$$

where:- $\pi_{\mathrm{i}} \square \mathrm{i}=1,2, \ldots \mathrm{n} \Omega$ is the $\mathrm{i}^{\text {th }}$ probability of households saving status given the vector of predictors $(\mathrm{X})$ By algebraic manipulation, the logistic regression equation can be written as in terms of an odds ratio:

$$
\begin{gathered}
\pi=\frac{P(y=1 / X i)}{1-p(y=1 / X i)}=\exp \left(\beta_{o}+\beta_{1} X_{1}+\beta_{2} X_{2}+\ldots .+\beta_{k} X_{k}\right)=\exp \left(X_{i}^{\prime} \beta\right) \\
\log \left(\frac{P(y=1 / X i)}{1-p(y=1 / X i)}\right)=\log \left(\frac{\pi_{i}}{1-\pi_{i}}\right)=\beta_{o}+\beta_{1} X_{1}+\beta_{2} X_{2}+\ldots+\beta_{k} X_{k}=X_{i}^{\prime} \beta
\end{gathered}
$$

where: $i=1,2, \ldots, \mathrm{k}$

The coefficient is interpreted as the change in the log-odds of saving status per unit change of the corresponding continuous covariate. In case of categorical predictor variable, it is interpreted as the log-odds of saving status given a category compared to the reference category (Dayton, 1992).

\section{RESULT AND DISCUSSION}

\subsection{Demographic Characteristic of Respondent}

From the total respondent of the study $205(82.3 \%)$ of them were male whereas $44(17.7 \%)$ of them were females. Based on the age distribution, most of them were aged in between 36-45 and 26-35, which 36.9\% and 35.3\%, respectively. Similarly, one can see other demographic character of the respondents from Table 1. 
Table 1: Demographic characteristic of respondent

\begin{tabular}{|l|l|c|c|}
\hline Characteristics & Category & Frequency & Percentage (\%) \\
\hline \multirow{4}{*}{ Agender } & Male & 205 & 82.3 \\
\cline { 2 - 4 } & Female & 44 & 17.7 \\
\hline \multirow{5}{*}{ Marital status } & $18-25$ & 36 & 35.5 \\
\cline { 2 - 4 } & $26-35$ & 88 & 36.9 \\
\cline { 2 - 4 } & $36-45$ & 92 & 12.0 \\
\cline { 2 - 4 } & 46 and above & 30 & 10.8 \\
\hline \multirow{5}{*}{ Religion } & Single & 27 & 88.8 \\
\cline { 2 - 4 } & Married & 221 & .4 \\
\cline { 2 - 4 } & Divorced/widowed & 1 & 34.5 \\
\hline \multirow{5}{*}{ Education Household heads } & Muslim & 88 & 56.2 \\
\cline { 2 - 4 } & Orthodox & 140 & 8.8 \\
\cline { 2 - 4 } & Protestant & 22 & 0.4 \\
\cline { 2 - 4 } & others & 1 & 41.8 \\
\cline { 2 - 4 } & Not educated & 104 & 34.9 \\
\cline { 2 - 4 } & Primary & 87 & 23.3 \\
\hline Kebele of respondent & Secondary and above & 58 & 35.7 \\
\cline { 2 - 4 } & Gembi Birjie & 89 & 18.1 \\
\cline { 2 - 4 } & Ada'a Melkie & 45 & 27.7 \\
\cline { 2 - 4 } & Selelkula & 69 & 18.5 \\
\hline
\end{tabular}

\subsection{Saving behavior of the households}

The following figure 1 showed that most of the respondents $(85.5 \%)$ saved their money in financial institution while about $14.5 \%$ of them not saved their money in financial institutions.

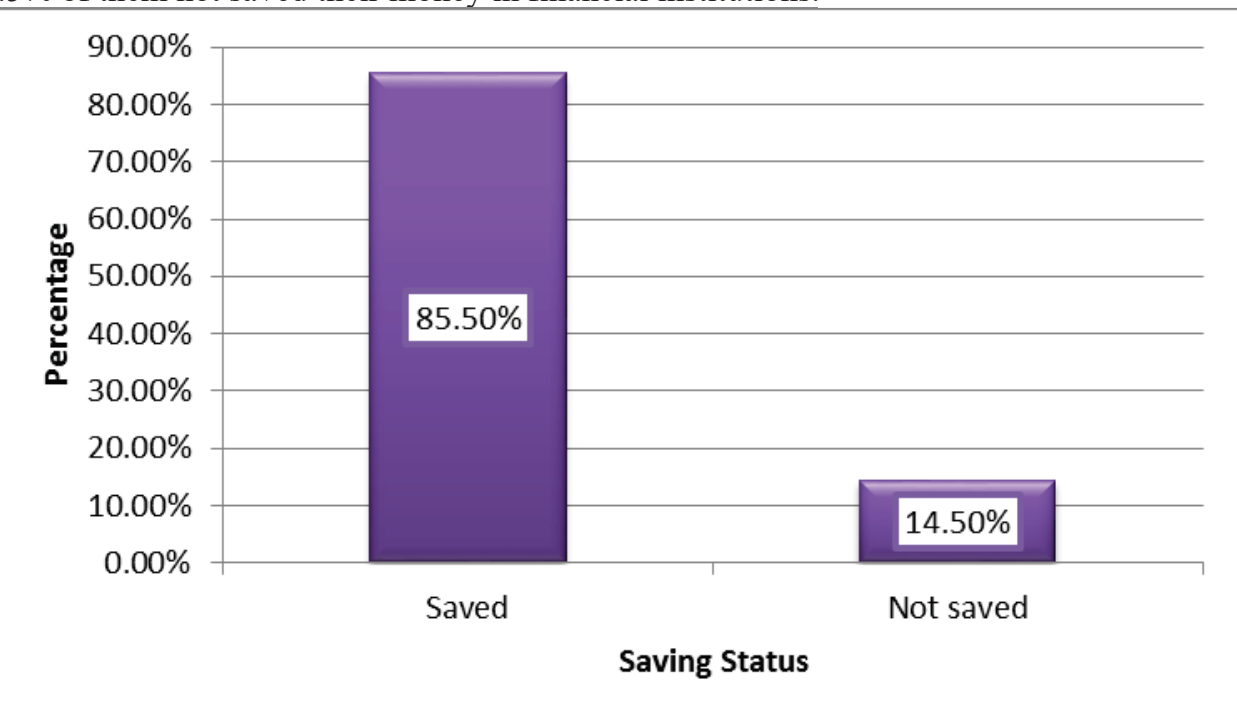

Figure 1: Saving status of the respondents

The respondent saved amount in birr(Ethiopian currency) runs between 0 to 160,000 birr with standard deviation 24499.28 birr and mean annual saved birr 18,543.43.

On average the respondent have 3.87 family sizes with minimum and maximum 1 and 9 respectively. Additionally, the mean annual total income the household was 78131.71 birr and on average 7.29 kilometers far from the financial institutions.

Table 2: Summary of some variables

\begin{tabular}{|l|l|c|c|c|}
\hline & minimum & Mean & maximum & Std. deviation \\
\hline Saved amount in birr & 0 & $18,543.43$ & 160,000 & $24,499.28$ \\
\hline Family size & 1 & 3.86 & 9 & 1.979 \\
\hline Total income & 14,400 & $78,131.71$ & 200,000 & $39,855.89$ \\
\hline Distance to & 1 & 7.29 & 17 & 5.549 \\
\hline
\end{tabular}




\subsection{Saving behavior vs Demographic and Socio-economic variables}

The major socioeconomic and demographic related characteristic of the respondents was presented in Table 3 . Out of the total respondent of $249,14.5 \%$ of them were not saved their money in financial institution while $85.5 \%$ of save in financial institutions.

With regard to Sex of the respondent, Male respondents (15.6\%) were highest non-saver than female respondents $(9.1 \%)$ and most of female respondent were more saver than Males. Similarly, based on the age distribution, those who aged 46-55 were the highest non-saver (36.7\%) than the others and those who aged 36-45 were the lowest non-saviors $9.8 \%$.

As the education level of respondent increase the percentage of saving behavior also increase. The percentage of non-saver based the education level varies $6.7 \%, 16.1 \%$ and $25.9 \%$ of uneducated, primary and secondary and above education level, respectively.

The percentages of saving status based on marital status the respondent increase as one move from single to married. Additionally, the percentage of non-saver varied from $7.4 \%$ and $15.4 \%$ for those who were single and married, respectively. Similarly, the percentages of saving behavior vary based on religion of respondent and the highest non-saver were $15.7 \%$ of those who were orthodox followed by $12.8 \%$ of Muslim and the least were protestant $9.1 \%$.

Those respondents who live in Gundo meskel 02 kebele $(91.1 \%)$ were more savers than who live in Dembi Birjie (88.8\%), Ada'a melkie (82.6\%) and Selelkula (78.3\%). Whereas the non-savers varied from $11.2 \%, 8.9 \%$, $17.4 \%$ and $21.7 \%$ for those who lived in Dembi Birjie, Ada'a melkie and Selelkula, respectively. Saving behavior of the vary cross the main occupation of the respondent $65.5 \%$ to $100 \%$ and petty trader were the lowest non-saver $(0.00 \%)$ while employed respondent were the highest non-saver(34.3\%). Similarly, one can check the respondent saving and non-saving distribution from Table3.

In general, one can see the chi-square test of association between the saving status and the different factors in Table 3 of column chi-square test. At 5\% level of significance, the chi-square test of association showed that the variable age, education level of Household head, main occupation, having farm land, getting advice to save and preference of institution were significantly associated with saving status where gender, marital status, religion and kebeles were not significant.

Table 3: Saving behavior vs demographic, Socio-economic

\begin{tabular}{|c|c|c|c|c|}
\hline \multirow{3}{*}{ Variables } & \multirow{3}{*}{ Category } & \multicolumn{2}{|c|}{ Saving behavior } & \multirow[t]{2}{*}{ Chi-square Test } \\
\hline & & Saved & Not saved & \\
\hline & & Frequency $(\%)$ & Frequency $(\%)$ & $\begin{array}{c}\text { Pearson value (p- } \\
\text { values) }\end{array}$ \\
\hline \multirow[t]{2}{*}{ Gender } & Female & $40(90.9)$ & $4(9.1)$ & \multirow{2}{*}{$\begin{array}{c}1.245 \\
(0.265)\end{array}$} \\
\hline & Male & $173(84.4)$ & $32(15.6)$ & \\
\hline \multirow[t]{4}{*}{ Age } & $18-25$ & $32(88.9)$ & $4(11.1)$ & \multirow{4}{*}{$\begin{array}{c}14.47 \\
(\mathbf{0 . 0 0 6 )}\end{array}$} \\
\hline & $26-35$ & $76(86.4)$ & $12(13.6)$ & \\
\hline & $36-45$ & $83(90.2)$ & $9(9.8)$ & \\
\hline & 46 and above & $19(63.3)$ & $11(36.7)$ & \\
\hline \multirow[t]{2}{*}{ Marital status } & Single & $25(92.6)$ & $2(7.4)$ & \multirow{2}{*}{$\begin{array}{c}1.4 \\
(0.495)\end{array}$} \\
\hline & Married & $187(84.6)$ & $34(15.4)$ & \\
\hline \multirow[t]{3}{*}{ Religion } & Muslim & $75(87.2)$ & $11(12.8)$ & \multirow{3}{*}{$\begin{array}{c}6.8 \\
(0.079)\end{array}$} \\
\hline & Orthodox & $118(84.3)$ & $22(15.7)$ & \\
\hline & Protestant & $20(90.9)$ & $2(9.1)$ & \\
\hline \multirow[t]{3}{*}{ Education Household heads } & Not educated & $97(93.3)$ & $7(6.7)$ & \multirow{3}{*}{$\begin{array}{c}11.30 \\
(\mathbf{0 . 0 0 4 )}\end{array}$} \\
\hline & Primary & $73(83.9)$ & $14(16.1)$ & \\
\hline & Secondary and above & $43(74.1)$ & $15(25.9)$ & \\
\hline \multirow[t]{4}{*}{ Kebele of respondent } & Dembi Birjie & $79(88.8)$ & $10(11.2)$ & \multirow{4}{*}{$\begin{array}{c}4.37 \\
(0.228)\end{array}$} \\
\hline & Gundomeskel 02 & $41(91.1)$ & $4(8.9)$ & \\
\hline & Ada'a Melkie & $57(82.6)$ & $12(17.4)$ & \\
\hline & Selelkula & $36(78.3)$ & $10(21.7)$ & \\
\hline \multirow{4}{*}{ Main occupation } & Farmer & $126(92.6)$ & $10(7.4)$ & \multirow{4}{*}{$\begin{array}{l}31.405 \\
\mathbf{( 0 . 0 0 0 )}\end{array}$} \\
\hline & Petty Trader & $26(100.0)$ & $0(0.00)$ & \\
\hline & Casual Laborer & $15(88.2)$ & $2(11.8)$ & \\
\hline & Employment & $46(65.5)$ & $24(34.3)$ & \\
\hline \multirow[b]{2}{*}{ Have farm land } & Yes & $123(92.5)$ & $10(7.5)$ & \multirow{2}{*}{$\begin{array}{l}16.05 \\
\mathbf{( 0 . 0 0 )}\end{array}$} \\
\hline & No & $79(7502)$ & $26(24.8)$ & \\
\hline \multirow[t]{2}{*}{ Have livestock } & Yes & $101(91.0)$ & $10(9.0)$ & \multirow{2}{*}{$\begin{array}{c}8.239 \\
(\mathbf{0 . 0 1 6 )}\end{array}$} \\
\hline & No & $101(79.5)$ & $26(20.5)$ & \\
\hline
\end{tabular}




\begin{tabular}{|c|c|c|c|c|}
\hline \multirow{3}{*}{ Variables } & \multirow{3}{*}{ Category } & \multicolumn{2}{|c|}{ Saving behavior } & \multirow[t]{2}{*}{ Chi-square Test } \\
\hline & & Saved & Not saved & \\
\hline & & Frequency (\%) & Frequency (\%) & $\begin{array}{l}\text { Pearson value (p- } \\
\text { values) }\end{array}$ \\
\hline \multirow[t]{2}{*}{ Get advice to save } & Yes & 189(88.7) & $24(11.3)$ & \multirow{2}{*}{$\begin{array}{c}26.35 \\
(\mathbf{0 . 0 0 0 )}\end{array}$} \\
\hline & No & $13(52.0)$ & $12(48.0)$ & \\
\hline \multirow[t]{2}{*}{ Prefer institution } & Formal & $187(88.2)$ & $25(11.8)$ & \multirow{2}{*}{$\begin{array}{c}8.195 \\
\mathbf{( 0 . 0 0 4 )}\end{array}$} \\
\hline & Informal & $26(70.3)$ & $11(29.7)$ & \\
\hline \multirow[t]{2}{*}{ Know interest rates } & Know & $176(91.7)$ & $16(8.3)$ & \multirow{2}{*}{$\begin{array}{c}25.43 \\
\mathbf{( 0 . 0 0 0 )}\end{array}$} \\
\hline & Not know & $37(64.9)$ & $20(35.1)$ & \\
\hline
\end{tabular}

\subsection{Determinants of household saving behavior}

The binary logistic regression in Table 4 showed that age of household head, in occupation of the household, knowing interest rate of formal financial institution, income of the household and family size were significantly influence saving status of the household in the district at $5 \%$ level of significance while education level of household head, and distance from the financial institution were not significantly influence the saving status of the households. Effects of these factors on saving status of the household were interpreted in terms of odds ratio and discussed as follows.

Ages of household head was significantly affect saving status of the households at $5 \%$ level of significance and the odds not saving for the household head who aged 26-35 and 46 and above was 6.22 and 2.78 times higher than those who aged 18-25, respectively, keeping other factors constants. This finding was in line with the previous study done by Quartey \& Blankson, (2008), Bizuneh (2011), Njung'e (2013), Michael (2013), Girma et al. (2013), Mirach and Hailu,(2014), Bogale Y. et al (2017) and Saliya, A. Y.(2018) that ages of the households positively related to households saving status. As the ages of the households age increase, the saving behaviors of the also increase.

Main occupations of the household significantly influence the saving status of the households at $5 \%$ level of significance and the odds of not saving for those households who were petty traders, casual laborer and employed were $23.50,20.615$ and 135.03 times more than those whose main occupation was farmer, respectively, keeping other factors constant. This finding was in line with the previous study done by Gina et al.(2012), Nayak (2013), Njung'e (2013), Obi-Egbedi et al. (2014), Mirach and Hailu,(2014) and Bogale Y. et al (2017) that employment status of the households related to the saving behavior of the household.

Knowing about the interest rate of financial institution of the household significantly influence the saving status of the households at $5 \%$ level of significance and the odds of not saving for those households who do not know about the interest rate of financial institution was 20.88 times more than those who know about the interest rate, keeping other factors constant. This finding was in line with the previous study done by Nayak (2013), Roba(2013) and Mirach and Hailu,(2014) that the awareness of interest rate encourages the saving of individuals and saving behavior.

Income of the household significantly influence the saving status of the households at $5 \%$ level of significance and as the income the household increase by one unit, the households not saving decrease by .999 times, keeping other factors constant. This finding was in line with previous study done by Bizuneh (2011), Popovici (2012), Workineh (2013), Raba (2013), Njung'e (2013), Michael (2013), Girma et al. (2013), Mirach and Hailu,(2014) Obi-Egbedi et al. (2014), Halefom Y. (2015), Bogale Y. et al (2017) and Saliya, A. Y.(2018) that income of the household positively related with saving behavior of the households implies that as the income of the households increase, saving also increase.

Family size of the household also significantly influence saving status of the households at $5 \%$ level of significance and as the number of family size increase by one person, the household not saving decrease by 0.595 times, keeping other factors constant. This finding was in line with the previous study done by Popovici (2012), Obayelu (2012), Michael (2013), Obi-Egbedi et al. (2014) and Bogale Y. et al (2017) that family size was negatively related to household saving status implies that the higher family size reduce saving of the family. 
Table 4: Factors affecting saving status of the households

\begin{tabular}{|c|c|c|c|c|c|c|}
\hline Categories & $\begin{array}{l}\text { Odds } \\
\text { (OR) }\end{array}$ & S.E & Z & P-values & \multicolumn{2}{|c|}{$95 \%$ CI of OR } \\
\hline $\begin{array}{l}\beta_{\text {o }} \text { (constant) } \\
\text { Age of HH (Ref: 18-25) } \\
26-35 \\
36-45 \\
46 \text { and above } \\
\text { Education (Ref: No education) } \\
\text { Primary education } \\
2^{\text {ndary and above }} \\
\text { Main occupation(Ref: Farmer) } \\
\text { Petty Trader } \\
\text { Casual Laborer } \\
\text { Employed } \\
\text { Know Interest Rate(Ref: know) } \\
\text { Not know } \\
\text { Income in birr } \\
\text { Distance to financial institution } \\
\text { Family size }\end{array}$ & $\begin{array}{l}0.028 \\
6.225 \\
8.153 \\
2.788 \\
1.180 \\
0.332 \\
23.508 \\
20.615 \\
135.031 \\
\\
20.884 \\
0.999 \\
0.956 \\
0.595\end{array}$ & $\begin{array}{l}5.839 \\
10.673 \\
4.966 \\
\\
1.0924 \\
.330 \\
\\
32.229 \\
32.606 \\
185.603 \\
15.463 \\
0.00014 \\
0.066 \\
0.1575\end{array}$ & $\begin{array}{l}-2.23 \\
1.95 \\
1.60 \\
4.45 \\
0.18 \\
-1.11 \\
2.30 \\
1.91 \\
3.61 \\
4.10 \\
-2.76 \\
-0.64 \\
-1.96\end{array}$ & $\begin{array}{l}0.026^{*} \\
0.051^{*} \\
0.109 \\
0.000^{* *} \\
0.858 \\
0.267 \\
0.021^{*} \\
0.056^{*} \\
0.000^{* *} \\
0.000^{* *} \\
0.006^{*} \\
0.521 \\
0.050^{*}\end{array}$ & $\begin{array}{l}0.146 \\
0.9905 \\
0.626 \\
0.849 \\
\\
0.1923 \\
0.0471 \\
\\
1.600 \\
0.928 \\
9.398 \\
\\
4.893 \\
0.999 \\
0.834 \\
0.355\end{array}$ & $\begin{array}{l}0.650 \\
39.128 \\
106.080 \\
9.154 \\
\\
7.242 \\
2.333 \\
\\
345.323 \\
45.763 \\
194.012 \\
\\
89.141 \\
0.999 \\
1.096 \\
1.002\end{array}$ \\
\hline LR $\operatorname{chi} 2(12)=113.42$ & & & & & & \\
\hline
\end{tabular}

(Ref: Reference category, $*, * *$ significant at $1 \%, 5 \%$ level of significance)

Data Source: On Survey (2019)

\section{CONCLUSION AND RECOMMENDATION}

The study aimed to assess and investigated saving behaviors of the household and it associated factor in the district based on a random sample of 249 households from four kebeles of the district. It also used quantitative primary data taken by using survey methods and analyzed using descriptive and inferential analysis methods.

The descriptive analysis revealed that out of 249 household, about 36(14.5\%) of them not saved their money in financial institutions whereas about $213(85.5 \%)$ of them saved their money in financial institutions. The factor such as age of household head, education level of household head, main occupation of the households, having farm land, getting advice about saving, knowing about financial institution interest rate, having livestock and preference on the types financial institution were statistically associated with saving status of the households.

The logit model also identified that the variables such as age of household head, main occupation of the household, knowing interest rate of formal financial institution, income of the household and family size were statistically significant determinants of saving status of the household in the district.

Therefore to improve the household's saving behavior in financial institutions, the district financial sector and institution, the Oromia regional state and the government financial sectors should work on awareness creation and promotions about saving and its advantage in improving and sustaining the economic growth of the community.

\section{REFERENCES}

Agresti A. (2007): An introduction to categorical data analysis (2nd Ed.). New York: John Wiley \& Sons

Bizuneh, Z. S. (2011). Determinants of household saving behavior in Ethiopia: A case study in Nekemte town(Master's thesis). Mekelle University, Mekelle, Ethiopia.

Bogale Yadeta Lidi, Amsalu Bedemo and Melkamu Belina (2017): Determinants of Saving Behavior of Households in Ethiopia: The Case Benishangul Gumuz Regional State. Journal of Economics and Sustainable Development www.iiste.org ISSN 2222-1700 (Paper) ISSN 2222-2855 (Online) Vol.8, No.13, 2017

Central Statistical Agency (CSA) and ICF International. 2012. "Ethiopia Demographic and Health Survey 2011.” Addis Ababa and Calverton, Maryland, USA: Central Statistical Agency and ICF International

Cochran, W.G. 1977. Sampling Techniques, $3^{\text {rd }}$ ed. John Wiley \& Sons Inc, Singapore.

CSA 2013. Population Projection of Ethiopia for All Regions at Wereda Level from 2014 - 2017: Addis Ababa, Ethiopia

Dayton, C.M. 1992. Logistic Regression Analysis. Department of Measurement, Statistics and Evaluation, 
University of Maryland

Gedela Surya Prakasa .2012. Determinants of Saving Behavior in Rural and Tribal Households: An Empirical Analysis of Visakhapatnam District, International Journal of Research in Social Sciences, 2(8).

Gina A. N., Rainier D. M and David, A. (2012). "Determinants of saving among low-income individuals in rural Uganda: Evidence from assets Africa", Journal of Advances in Applied Sociology, 2 (4), 280-291.

Girma,T., Belay, K., Bezabih, E. and Jema, H. (2013). "Determinants of rural household savings in Ethiopia: The case of East Hararghe zone, Oromia regional state". Journal of Economics and Sustainable Development, 4 (3).

Halefom,.Y. (2015). "Determinants of household saving in Gedeo zone, Southern Ethiopia". Journal of Economics and Sustainable Development, 6 (7).

Karim Moussaly. 2010. Participation in Private Retirement Savings Plans, 200868 (1), 192-204.

McCullagh, P. and J.A. Nelder, 1989. Generalized Linear Models, $2^{\text {nd }}$ Edn. Chapmann and Hall, London

Michael,K. (2013). "Savings habit and use of savings among households in Ga-East municipality", Dissertation submitted to the University of Ghana, Legon in partial fulfillment of the requirement for the award of a master of philosophy development studies degree.

Nayak, S. "Determinants and Pattern of Saving Behaviour in Rural Households of Western Odisha, 2013."National Institute of Technology Rourkela-769008, India.

Njung'e, P.M. (2013). “Gender and household savings behavior in Kenya”, Research paper submitted in partial fulfillment of the requirements for the degree of Master of Arts in economics of the University of Nairobi.

Obayelu, A. (2012). "Saving behavior of rural households in Kwara State, Nigeria". African Journal of Basic and Applied Sciences, 4 (4): 115-123.

Obi-Egbedi,o.,Alawode,o. and Soneye, A. (2014). "Savings determinants among rural households in Southwest Nigeria", World Rural Observer, 6(4):6-11

Oladipo (2010) Does saving really matter for growth in developing countries? The case of a small open economy. Int. Bus. Econ. Res. J., 9 (April (4)) (2010) USA

Ondiege P. (2012) NY cited conference

Popovici, G. (2012). "Understanding the factors affecting savings of Dutch households", Master thesis MSc. University of Groningen and "Alexandru Ioan Cuza" University of Iasi

Quartey and Blankson, S. (2008). "Household savings in Ghana: 'Does Policy Matter' in the economy of Ghana: Analytical perspective on stability, growth and poverty", James curry with publishing services, Accra New Town, Ghana.

Roba, G. (2013). "The Role of saving and loan in economic growth of Ethiopia. Proceedings of conference on loan and saving: the role in Ethiopian socio-economic development", Harmaya University, Dire Dawa, Ethiopia.

Saliya, A. Y.(2018).Determinants of Urban Household Saving Behavior in Ethiopia: A Survey Study in Mekelle City. Üniversitepark Bülten,7(2), 82-95.

Tadele, Mengesha (2015). "Household saving behavior in Jimma zone of Oromia Region, Ethiopia", International Journal of Research in Commerce, It and Management, 5(3)

Tsega Hagos and Yemane Michael .2014. Determinants of household saving in Ethiopia: A case of North Gondar Zone, Amhara Regional State, Ethiopia. International Journal of Development and Economic Sustainability, 2(4): 37-49.

Workineh, A. (2014). "The determinant of saving behavior of women's in Urban Ethiopia", the case of Arba Minch town, Journal of Developing Country Studies, 4 (21).

Yamane Taro. 1969. Statistics, an Introductory Analysis. 2nd Edition. Harper and Row Inc., New York

Yao, R., Wang, F., Weagley, R. O., Liao, L. 2011. Household saving motives: Comparing American and Chinese consumers. Family and Consumer Sciences Research Journal, 40, (1): 28-44. 